Volume 2 Issue 1, March 2018: pp. 403-415. Copyright (C) 2018 HOLREV. Faculty of Law, Halu Oleo University, Kendari, Southeast Sulawesi, Indonesia. ISSN: 2548-1762 | e-ISSN: 2548-1754. Open Access at: http://ojs.uho.ac.id/index.php/holrev/

\title{
Pemulihan Hak Politik Melalui Mekanisme Konstitusional
}

\author{
Restoration of the Political Rights Through \\ Constitutional Mechanism
}

\author{
Handrawan \\ Dosen Fakultas Hukum Halu Oleo \\ E-mail: handrawansaranani84@gmail.com
}

\begin{abstract}
This study aimed to find a new reasoning in the previous theory. The used method is normative research by applying conceptual and statute approach. This research revealed that politic rights is restricted by derogable rights hence political rights was not the same as civil rights which is not also limited by non derogable rights. The fulfillment on political rights can only be done if it has attained a basic obligation. The Universal Declaration of Human Rights and the ICCPR have not yet regulated revocation of political rights, but it regulated in national legislation. Revocation of political rights can only be done through the judicial mechanism. The removal of political rights without judicial mechanism is considered as an unconstitutional hence political rights are the rights of the citizens protected both in the context of human rights and in the context of democracy. The restoration of political rights without judicial mechanism can be done by using the executive mechanism by means of Article 14 Paragraph (1) and 14 Paragraph (2) UUD NRI 1945 on Amnesty, Abolition, pardon and rehabilitation while restoration of political rights with justice mechanism can only be done by taking legal action as defined in the Criminal Procedural Code (KUHAP). The findings in this paper are the restoration of political rights necessary to maintain the integrity of democracy in the context of the rule of law because the removal of political rights non-justice mechanism would lose for democracy. Thus, democracy has coherence with the political participation of citizens in order to produce the quality of democracy.
\end{abstract}

Keyword: restoration, political rights, constitution.

Abstrak: Penelitian ini bertujuan untuk mengembangkan reasionong baru dalam teori lama. Penelitian ini merupakan penelitian normatif dengan pendekatan konsep (conceptual approach) dan pendekatan perundang-undangan (statute approach). Hasil penelitian ini menunjukkan bahwa hak politik bersifat dapat dibatasi (derogable right) sebab hak politik bukanlah hak sipil yang tidak boleh dibatasi (non derogable right). Pemenuhan hak politik hanya dapat dilakukan apabila telah terpenuhinya kewajiban asasi. Dalam DUHAM dan ICCPR pencabutan hak politik tidak diatur namun hal tersebut diatur di dalam peraturan-perundang-undangan 
nasional. Pencabutan hak politik hanya dapat dilakukan melalui mekanisme peradilan. Pencabutan hak politik tanpa melalui mekanisme peradilan adalah inkonstitusional sebab hak politik merupakan hak warga negara yang dilindungi baik dalam konteks hak asasi manusia maupun dalam konteks demokrasi. Pemulihan hak politik tanpa melalui mekanisme peradilan dapat dilakukan dengan menggunakan mekanisme eksekutif melalui Pasal 14 Ayat (1) dan14 Ayat (2) UUN NRI 1945 tentang Amnesti, Abolisi, grasi dan rehabilitasi sedangkan pemulihan hak politik melalui mekanisme peradilan hanya dapat dilakukan dengan melakukan upaya hukum biasa sebagaimana yang telah diatur di dalam KUHAP. Temuan dalam tulisan ini adalah pemulihan hak politik perlu dilakukan demi menjaga keutuhan demokrasi dalam konteks negara hukum sebab pencabutan hak politik tanpa melalui mekanisme peradilan akan menyebabkan demokrasi kehilangan makna. Demokrasi memiliki koherensi dengan partisipasi politik warga negara untuk menghasilkan kualitas demokrasi yang baik.

Kata kunci: pemulihan, hak politik, konstitusional.

\section{PENDAHULUAN}

Pembahasan mengenai sejarah hak politik tentu saja tidak bisa dilepaskan dari pembahasan mengenai sejarah hak asasi manusia. Kedua hal ini sangat berkaitan erat karena posisi hak politik sebagai bagian yang tidak terpisahkan dari hak asasi manusia. Hak sipil dan politik sendiri dalam sejarah hak asasi manusia dikenal sebagai generasi pertama perkembangan hak asasi manusia. ${ }^{1}$ Hak yang telah lama dikenal dan selalu diasosiasikan dengan pemikiran di negara-negara barat. ${ }^{2}$

Pada awalnya, pembahasan mengenai hak asasi manusia termasuk di dalamnya hak politik, berawal dari konflik-konflik kekuasaan di berbagai negara barat. Konflik ini bersumber dari pertentangan antara kekuasaan para raja dan para ulama gereja yang saling mengakui bahwa dirinya memiliki kekuasaan yang bersifat mutlak dan titah yang bersifat universal.

Hak politik merupakan generasi pertama dari hak asasi manusia. Hak politik yang pertama kali diakui di antaranya adalah hak atas kebebasan, persamaan (equality) dan hak menyatakan pendapat. ${ }^{3}$ Hak-hak politik tersebut terangkum dalam berbagai instrumen awal hak asasi manusia di berbagai negara, seperti dalam Bill of Rights (1689) Inggris,

\footnotetext{
1 Scott Davidson, Hak Asasi Manusia: Sejarah, Teori, dan Praktek dalam Pergaulan Internasional, terjemahan A. Hadyana Pudjaatmaka, Pustaka Utama Grafiti, Jakarta, 1994. hlm. 1.

2 Miriam Budiardjo, Dasar-Dasar Ilmu Politik, Jakarta: PT. Gramedia Pustaka Utama, 2008, hlm. 212.

3 Ibid., hlm. 215.
} 
Declaration des Droits de I'Homme et du Citoyen Prancis (1789), dan konstitusi Amerika Serikat (1791). ${ }^{4}$

Bill of Rights (1689) adalah bentuk perkembangan dokumen Magna Charta (1215) DI Inggris. Jika dalam Magna Charta (1215) hanya dikenalkan mengenai pembatasan kekuasaan dalam hubungan antara raja dan para bangsawan, maka dalam Bill of Rights (1689) hak-hak atas kebebasan individu sebenarnya baru mulai dibicarakan. Bill of Rights (1689) menjamin kepentingan kaum borjuis Inggris dan mengatur hal tertentu yang berciri hak asasi manusia. Akan tetapi sisi jaminan hak yang ditonjolkan dalam Bill of Rights (1689), dapat dikatakan sedikit dan berat sebelah, serta menguntungkan golongan warga negara tertentu. Di luar berbagai kekurangannya, Bill of Rights (1689) tetaplah instrumen yang sangat penting karena ia mencoba menggantikan tindakan yang tidak diduga-duga dan absolutisme monarki yang sewenang-wenang dengan legitimasi konstitusional oleh parlemen. ${ }^{5}$ Sehingga dapat dikatakan, bentuk hak yang dijamin di sini masih dalam koridor hak sipil dan politik yang merupakan generasi pertama dari hak asasi manusia.

Setelah Revolusi Pancasila, lahirlah dokumen yang disebut Declaration des Droits de I'Homme et $d u$ Citoyen Prancis (1789). Pejuang Revolusi Pancasila menginginkan hancurnya sistem pemerintahan absolut digantikan sistem orde baru yang demokratis. Kedaulatan negara harus berada ditangan rakyat, sehingga pemerintahan seharusnya dilaksanakan oleh rakyat dan untuk rakyat. Dalam pasal 2 Declaration des Droits de I'Homme et du Citoyen Prancis (1789) diatur:

Sasaran setiap asosiasi politik adalah pelestarian hak-hak manusia yang kodrati dan tidak dapat dicabut. Hak-hak ini adalah [hak atas] kebebasan. Kebebasan berarti dapat melakukan apa saja yang tidak merugikan orang lain; jadi pelaksanaan hak-hak kodrati setiap manusia tidak dibatasi kecuali oleh batas-batas yang menjamin pelaksanaan hakhak yang sama ini bagi anggota masyarakat yang lain. Batas-batas ini hanya dapat ditetapkan oleh undang-undang. ${ }^{6}$

Hal yang hampir sama terjadi di Amerika Serikat. Pada awalnya, konsepsi hak-hak asasi manusia terdapat dalam Virginia Bill of Rights. Dokumen ini mencantumkan beberapa kebebasan yang harus dilindungi dari campur tangan negara, di antaranya

\footnotetext{
4 Djali et.al, Hak Asasi Manusia (Suatu Tinjauan Teoritis dan Aplikasi), Jakarta: CV, Restu Agung, 2013. hlm. 7.

5 Scott Davidson, Op. Cit, hlm. 2-5.

6 Ibid., hlm. 5-6.
} 
kebebasan pers, kebebasan beribadah, dan ketentuan lain mengenai kebebasan yang tidak dapat dicabut tanpa berdasarkan hukum setempat atau pertimbangan masyarakat. Virginia Bill of Rights ini sedikit banyak menyumbang pemikiran para perumus Konstitusi Amerika Serikat dalam memasukkan perlindungan hak-hak manusia tersebut. Pada tahun 1791, Amerika Serikat bahkan mengadopsi Bill of Rights yang memuat hak-hak individu yang dijaminnya. Pada perkembangannya, terjadi beberapa amandemen konstitusi yang menambahkan perlindungan atas beberapa hak yang belum diatur sebelumnya. Akan tetapi, amandemen ini tidak pernah mengurangi atau menghapuskan hak yang sebelumnya telah dilindungi konstitusi. ${ }^{7}$

Ketiga dokumen di atas, baik Bill of Rights (1689), Declaration des Droits de I'Homme et du Citoyen Prancis (1789), dan Konstitusi Amerika Serikat (1791) menunjukkan betapa besarnya peran Revolusi Inggris, Prancis serta Amerika dalam perkembangan hak politik Internasional. Perkembangan hak asasi manusia khususnya hak politik, ternyata tidak berhenti pada ketiga negara besar dunia tersebut. Setelah perang Dunia II, negara-negara di Dunia menginginkan adanya suatu instrumen hak sasi manusia yang bersifat universal. Atas dasar keinginan tersebut, pada tahun 1946, Perserikatan Bangsa-bangsa (PBB) kemudian membentuk sebuah Human Rights Committee. Komisi ini melahirkan satu instrumen perlindungan hak asasi manusia yang kita kenal dengan nama the Universal Declaration of Human Rights (1948). ${ }^{8}$ Selain memuat hak sipil dan politik, the Universal Declaration of Human Rights (1948) juga memuat hak ekonomi sosial dan budaya yang kemudian dikenal sebagai generasi kedua hak asasi manusia. ${ }^{9}$ The Universal Declaration of Human Rights (1948) mengatur rumusan hak dan kebebasan dengan sangat luas hingga seolah tanpa batas. Deklarasi ini memang sifatnya tidak mengikat secara yuridis, akan tetapi mempunyai pengaruh moral, politik, dan edukasi yang besar. The Universal Declaration of Human Rights (1948) bahkan pada akhirnya menjadi acuan perlindungan hak asasi manusia di berbagai negara di dunia. ${ }^{10}$

Keberadaan the Universal Declaration of Human Rights (1948) dalam perkembangannya dianggap kurang mampu mengakomodir perkembangan hak asasi manusia dalam masyarakat Internasional. Sebagai kelanjutan kerja, Human Rights Committee kemudian membentuk 2 kovenan yaitu the Internasional Covenant on Civil and

\footnotetext{
Ibid., h 4-5

8 Miriam Budiardjo, Op.Cit., hlm. 218.

9 Scott Davidson, "Intoduction", dalam Alex Conte et al, Op. Cit., hlm. 1.

10 Miriam Budiardjo, Op. Cit., hlm. 219.
} 
Political Rights (1966) dan the Internasional Covenant on Economic, Sosial, and Cultural Rights (1966). ${ }^{11}$ The Internasional Covenant on Civil and Political Rights (1966) inilah yang menjadi dasar perlindungan atas hak-hak sipil dan politik. Hak politik dalam kovenan ini berbicara mengenai jaminan individu untuk dapat ikut berpartisipasi secara penuh dalam masyarakat, seperti kebebasan partisipasi demokrasi dalam hak memilih dan di pilih pada jabatan publik, kebebasan berpendapat, dan sebagainya. ${ }^{12}$ Kovenan ini menjadi dasar yang kuat dalam pengembangan jaminan atas hak sipil dan politik di berbagai negara sampai hari ini, meskipun berdasarkan rumusan pasal 2kovenan dinyatakan bahwa hak-hak yang diatur di sini masih akan dihormati dan segera dijamin. The Internasional Covenant on Civil and Political Rights (1966) mengatur kewenangan Rights Committee mengawasi implementasi kovenan ini dan menetapkannya melalui suatu protokol fakultatif. Dalam protokol ini diatur mengenai mekanisme pengajuan petisi kepada Human Rights Committee. ${ }^{13}$

Pada dasarnya, perkembangan awal lahirnya hak asasi manusia adalah perkembangan awal lahirnya hak politik di Dunia. Mengingat hak sipil dan politik merupakan generasi pertama dari hak asasi manusia, sebelum muncul generasi kedua dan ketiga hak asasi manusia. Dasar dan hak yang paling awal disadari sebagai hak yang eksistensinya melekat dengan keberadaan manusia itu sendiri.

Hak politik sebagai hak warga negara menjadi simbol dari penghormatan, pemajuan dan perlindungan hak asasi manusia dan demokrasi dalam konteks negara hukum. Indonesia dalam perkembangannya pernah menghadapi dilema atas pengungkungan hak politik dan hal tersebut menjadi sejarah kelam bangsa Indonesia dalam bernegara.

Pembatasan dan pencabutan hak politik yang pernah terjadi di Indonesia tidak hanya terjadi karena seseorang telah melakukan perbuatan pelanggaran pidana berupa tindak pidana subversi terhadap kedaulatan negara tetapi pencabutan hak politik banyak dilakukan hanya untuk melindungi kepentingan kekuasaan, akibatnya pencabutan hak politik dilakukan tanpa melalui mekanisme peradilan.

Pencabutan hak politik tanpa melalui mekanisme peradilan merupakan wujud nyata dari pelanggaran HAM seperti kasus tuduhan terlibat dalam ideologi terlarang

\footnotetext{
11 Ibid.

12 Scott Davidson, "Introduction" dalam Alex Conte et al, Op.Cit., hlm. 2.

13 Scott Davidson, Op, Cit., hlm. 18.
} 
dalam kasus eks PKI. Keterlibatan secara langsung dalam ideologi terlarang tersebut merupakan tindakan yang tepat sebagai bentuk perlindungan kedaulatan ideologi negara yakni Pancasila. Namun demikian pencabutan hak politik terhadap yang tidak terlibat dan tidak mengetahui keterlibatannya tetapi dianggap terlibat merupakan tindakan sewenang-wenang yang telah dilakukan oleh rezim kekuasaan.

Labelisasi terhadap eks PKI masih terus menjadi perdebatan hingga saat ini, untuk itu perlu ada mekanisme pemulihan hak politik terhadap warga negara yang dianggap terlibat dalam ideologi terlarang agar menghilangkan stigma negatif terhadap warga negara. Untuk negara dalam hal ini presiden perlu melakukan tindakan pemulihan melalui mekanisme konstitusional.

Berdasarkan uraian latar belakang di atas, maka dapat dirumuskan suatu permasalahan bagaimanakah pemulihan hak politik melalui mekanisme konstitusional?

\section{METODE PENELITIAN}

Penelitian hukum ini merupakan penelitian Normatif dengan menggunakan metode pendekatan masalah yaitu Pendekatan konseptual (conceptual approach) ${ }^{14}$. Pendekatan konseptual dilakukan karena memang belum atau tidak ada aturan hukum untuk masalah yang akan diteliti. Oleh karena itulah dibangun suatu konsep yang menjadi acuan dalam penelitian tersebut.

\section{ANALISIS DAN PEMBAHASAN \\ Hak Politik Dalam Konstitusi}

Konstitusi Indonesia, Undang-Undang Dasar Negara Republik Indonesia Tahun 1945 merupakan konstitusi yang dinilai paling ideal bagi kehidupan ketatanegaraan Indonesia. Jika diingat, Indonesia pernah mengalami beberapa kali perubahan konstitusi dari Undang-Undang Dasar 1945 (naskah asli pasca proklamasi), Konstitusi Republik Indonesia Serikat 1949, Undang-Undang Dasar Sementara 1950, hingga yang terakhir Undang-Undang Dasar Negara Republik Indonesia Tahun 1945 (dengan 4 kali amandemen).

Sejak keluarnya Dekrit Presiden pada 5 Juli 1959, Undang-Undang Dasar 1945 (naskah asli pasca proklamasi) kembali berlaku dan secara otomatis mencabut

\footnotetext{
14 Peter Mahmud Marzuki, Penelitian Hukum, Edisi Revisi, Jakarta: Prenada Media Group, 2016, hlm. 177.
} 
keberlakuan Undang-Undang Dasar Sementara 1950 sebagai konstitusi. Jika diperbandingkan dengan Undang-Undang Dasar Sementara 1950, pengaturan mengenai hak asasi manusia khususnya hak politik mengalami kemunduran dengan pemberlakuan kembali Undang-Undang Dasar 1945 (naskah asli proklamasi). Sehingga atas berbagai pertimbangan dan alasan historis yang mengamanatkan penyempurnaan Undang-Undang Dasar 1945 (naskah asli pasca proklamasi), maka perubahan atau amandemen menjadi suatu hal yang tidak dapat dihindari. Undang-Undang Dasar 1945 (naskah asli pasca proklamasi) yang berlaku pada masa pemerintahan Soekarno dan Soeharto sering kali dinilai sebagai “tameng” untuk mempertahankan kekuasaan. Bahkan, Bagir Manan pernah berpendapat mengenai Undang-Undang Dasar yang dianggapnya sebagai biang KKN, pemasung semangat demokrasi dan penegakan hukum, dan memberi peluang tumbuhnya pemerintah yang otoriter, anti kritik, dan anti-perbedaan pendapat. akhirnya pada 19 Oktober 1999 dalam sidang umum MPR yang berlangsung tanggal 14-21 Oktober 1999 dilakukan perubahan pertama Undan-Undang Dasar 1945 (naskah asli pasca demokrasi). Tidak berhenti sampai di sana, perubahan-perubahan terus dilakukan. Sampai saat ini, telah terjadi 4 (empat) kali perubahan yaitu pertama, 19 Oktober 1999; kedua, 18 Agustus 2000; ketiga, 10 November 2001; dan keempat, 10 Agustus 2002. Undang-Undang Dasar 1945 (naskah asli pasca proklamasi) hasil perubahan pada akhirnya disebut berbeda dengan istilah Undang-Undang Dasar Negara Republik Indonesia Tahun 1945.

Terkait dengan perubahan muatan yang mengatur mengenai hak asasi manusia, perubahan kedua Undang-Undang Dasar 1945 pada 18 Agustus 2000 memiliki peran yang sentral. Hal ini dapat dilihat dari adanya bab khusus yang mengatur mengenai hak asasi manusia yaitu Bad XA yang merupakan ketentuan tambahan hasil perubahan UndangUndang Dasar 1945. Tidak hanya itu, di luar Bab XA pun masih dapat kita temukan muatanmuatan hak asasi manusia yang terbesar dalam beberapa bab dan pasal.

Hak politik sebagaimana dimaksud dalam sub bab ini diatur dalam beberapa pasal dalam Undang-Undang Dasar Negara Republik Indonesia Tahun 1945, antara lain pasal 27 ayat (1) dan pasal 28D AYAT (3). Isi rumusan pasal tersebut tertuang sebagai berikut:

Pasal 27

1. Segala warga negara bersamaan kedudukannya di dalam hukum dan pemerintahan dan wajib menjunjung hukum dan pemerintahan itu dengan tidak ada kecualinya. 
Pasal 28D

3. Setiap warga negara berhak memperoleh kesempatan yang sama dalam pemerintahan.

Kedua pasal tersebut menunjukkan bahwa konstitusi memberikan jaminan pengakuan hak politik khususnya terkait kesempatan untuk turut serta dalam pemerintahan. Keikutsertaan yang dimaksudkan dalam hal ini bisa pula diimplementasikan dalam hak seseorang untuk memilih dan dipilih dalam suatu pemilihan yang diadakan berdasarkan aturan-aturan umum seperti pemilihan umum Presiden dan wakil Presiden, DPR, DPD, DPRD, atau pemilihan kepala daerah baik Gubernur, bupati, maupun Walikota.

Hak politik dianggap sebagai suatu yang penting dalam koridor perlindungan hak asasi manusia. Undang-Undang Dasar Republik Indonesia Tahun 1945 juga mengatur secara jelas pengakuan dan perlindungan hak-hak politik warga negara sebagai wujud tanggung jawab negara. Ketentuan ini sesuai dengan rumusan pasal 28I ayat (4) dan ayat (5) Undang-Undang Dasar Republik Indonesia Tahun 1945 yang mengatur sebagai berikut:

Pasal 28I

(1) Perlindungan, pemajuan, penegakan, dan pemenuhan hak asasi manusia adalah tanggung jawab negara, terutama pemerintah.

(2) Untuk menegakkan dan melindungi hak asasi manusia sesuai dengan prinsip negara hukum yang demokratis, maka pelaksanaan hak asasi manusia dijamin, diatur, dan dituangkan dalam peraturan perundang-undangan.

Dalam pasal 28I ayat (5) tersebut dijelaskan bahwa bentuk perlindungan serta kepastian hukum dalam pemenuhan hak asasi manusia akan dituangkan dalam peraturan perundang-undangan, artinya selain dalam Undang-Undang Dasar Republik Indonesia Tahun 1945 nantinya akan dibentuk peraturan perundang-undangan lainnya yang mengatur penegakan dan perlindungan hak asasi manusia. Saat ini telah ada undangundang yang khusus mengatur mengenai hak asasi manusia itu sendiri yaitu UndangUndang Republik Indonesia No. 39 Tahun 1999 tentang hak asasi manusia. Selain itu terdapat pula ratifikasi The International Covenan on Civil and political Rights (1966) yang dituangkan dalam Undang-Undang Republik Indonesia No. 12 Tahun 2005 tentang pengesahan International Covenan on Civil and political Rights serta berbagai peraturan lain yang mengatur mengenai hak asasi manusia khususnya hak politik. 
Pengaturan hak asasi manusia Undang-Undang Dasar Republik Indonesia Tahun 1945 bukan berarti tanpa batasan. Perlu dipahami kembali bahwa konsep hak asasi yang selalu berbanding lurus dengan kewajiban asasi harus tetap diterapkan hal ini sesuai dengan apa yang diatur dalam pasal 28J sebagai berikut:

(1) Setiap orang wajib menghormati hak asasi manusia orang lain dalam tertib kehidupan bermasyarakat, berbangsa, dan bernegara.

(2) Dalam menjalankan hak dan kebebasannya, setiap orang wajib tunduk kepada pembatasan yang ditetapkan dengan undang-undang dengan maksud sematamata untuk menjamin pengakuan serta penghormatan atas hak dan kebebasan orang lain dan untuk memenuhi tuntutan yang adil sesuai dengan pertimbangan moral, nilai-nilai agama, keamanan, dan ketertiban umum dalam suatu masyarakat demokratis.

Ketentuan pembatasan dalam pasal 28J tersebut dapat dimaknai sebagai upaya untuk menjaga tertib bermasyarakat, dan bernegara.

\section{Pemulihan Hak Politik Melalui Mekanisme Konstitusional}

Pencabutan hak politik dilihat dari sejarah berdirinya negara Indonesia secara langsung maupun tidak langsung pernah dipraktikkan dalam rezim kekuasaan pada masa yang lalu, meskipun hal tersebut masih bisa diperdebatkan mengenai dicabutnya hak politik melalui tanpa proses peradilan. Aktor penting yang terlibat dalam gerakan-gerakan perlawanan ideologi bangsa Indonesia dengan mencoba melahirkan dan menumbuhkan ideologi baru sebut saja komunisme dari ajaran Karl Max telah diadili melalui proses peradilan, namun banyak masyarakat yang terlibat dalam gerakan itu baik sadar maupun tidak sadar, langsung ataupun tidak langsung melalui kekuasaan orde baru telah menghukum mereka dan menjustifikasi mereka melalui mekanisme pembatasan hak-hak di bidang politik, pendidikan, pekerjaan dan sosial. Justifikasi dan pencabutan hak politik yang terjadi terhadap mereka tanpa melalui mekanisme proses peradilan dibuktikan dengan adanya beberapa wilayah-wilayah tertentu yang dijadikan wilayah tahanan politik dan keberadaan wilayah tersebut masih ada dan terisolir.

Penulis pada tahun 2007 menjadi Peneliti mengenai Bantuan Hukum dan Pemberdayaan Bagi Masyarakat Miskin dan Terpinggirkan (Legal Empowerment and Assistance for the Disadvantaged)/LEAD di Sulawesi Tenggara pada bulan Juli s/d Agustus 2007 yang diselenggarakan oleh Lembaga Demografi Fakultas Ekonomi Universitas Indonesia. Dari hasil penelitian penulis diperoleh bahwa para tahanan politik yang dituduh 
melakukan tindakan subversif telah mengalami banyak diskriminasi terhadap berbagai aspek kehidupan dan bahkan mereka yang tidak terlibat terpenjara dalam satu wilayah terisolir dan tidak memperoleh pendidikan yang layak, sebagai akibat dari kesalahan yang tidak pernah dilakukan oleh orang tua mereka. Bias-bias kekecewaan tersebut sangat tergambar jelas dan bahkan sifat apatisme terhadap bangsa ini yang lebih terlihat dari penjelasan-penjelasan mereka. Labelisasi tentang tahanan politik masih menyelimuti kehidupan mereka meskipun pada era reformasi ini hak-hak konstitusional mereka telah dikembalikan, namun mekanisme pemulihan atas nama baik orang tua mereka belum dipulihkan.

Pada saat penulis melakukan penelitian tentang Legal Empowerment and Assistance for the Disadvantaged keadilan sosial tidak terwujud secara nyata. Ini dibuktikan tidak adanya fasilitas pendidikan, fasilitas kesehatan dan fasilitas penerangan yang diberikan oleh pemerintah kepada mereka, padahal wilayah tahanan politik berada dekat dengan wilayah Ibukota Provinsi, namun secara demografi wilayahnya terisolir dan sulit untuk dijangkau.

Pencabutan hak politik kategori kedua ini jika dilihat dari perspektif hak asasi manusia dan demokrasi dalam konteks negara hukum, maka pencabutan hak politik tanpa melalui proses peradilan merupakan bentuk nyata dari pelanggaran hak asasi manusia dan telah menyebabkan demokrasi kehilangan makna dalam sistem hukum Indonesia.

Ifdhal Kasim menyatakan bahwa pencabutan hak politik tanpa melalui proses peradilan dinilai sebagai salah satu kejahatan negara terhadap warga negaranya bahkan dianggap sebagai bagian pelanggaran hak asasi manusia. ${ }^{15}$ Dengan demikian pencabutan hak politik tidak dapat serta merta dilakukan termasuk dengan alasan kepentingan negara atau kondisi memaksa yang tidak dapat dibuktikan kebenarannya serta negara dalam hal pencabutan hak politik tanpa melalui proses peradilan tidak dapat bersembunyi atau menggunakan kewenangannya dalam membentuk peraturan dan kebijakan hukum sebagai sarana legitimasi pencabutan hak politik.

Pencabutan hak politik tanpa melalui peradilan merupakan bentuk konkret ketidakberdayaan hukum atas politik dan kekuasaan, akibatnya melahirkan dilema antara hukum dan kekuasaan. Upaya Pencabutan hak politik tanpa melalui proses peradilan

15 Wawancara dengan Rizki Ridha Damayanti, Hotel Oria Jakarta, Tanggal 19 September 2016. 
adalah upaya pelemahan demokrasi, pelemahan partisipasi warga negara di bidang politik demi kepentingan rezim kekuasaan yang tidak bermoral.

Pencabutan hak politik tanpa melalui mekanisme peradilan yang penulis sebut sebagai mekanisme inkonstitusional perlu mendapatkan perhatian sebab hal tersebut dapat menjadi preseden buruk dalam tatanan negara hukum. Hak politik baik dalam dimensi hak asasi manusia merupakan hak yang wajib untuk dilindungi begitu pula dalam dimensi demokrasi hak tersebut merupakan hak konstitusional warga negara. Argumentasi penguatan hak konstitusional, idealnya dijadikan argumentasi utama mendesain institusi demokrasi. ${ }^{16}$

Pemulihan hak politik perlu dilakukan dalam rangka menjaga nilai-nilai moral berbangsa dan bernegara dalam konteks negara hukum. merujuk pada mekanisme sistem peradilan pidana di Indonesia sekiranya tidak ada solusi terkait dengan mekanisme pemulihan hak politik tanpa melalui peradilan kecuali pemulihan hak politik melalui mekanisme peradilan yakni dapat mengacu kepada Pasal 233 dan Pasal 244 UndangUndang Nomor 8 Tahun 1981 tentang Kitab Undang-Undang Hukum Acara Pidana, yang selanjutnya disebut (KUHAP). Mekanisme upaya hukum luar biasa meliputi peninjauan kembali (PK) sebagaimana hanya dapat dimungkinkan jika terdapat alasan-alasan moral sebagaimana yang dimaksud dalam ketentuan Pasal 263 Ayat (2) KUHAP.. Namun demikian dari perspektif konstitusional maka ada langkah pemulihan melalui mekanisme eksekutif. mekanisme eksekutif tersebut dijamin oleh Undang-Undang Dasar Negara Republik Indonesia Tahun 1945 sebagai hak prerogatif presiden sebagai kepala negara bukan sebagai kepala pemerintahan.

Mekanisme pemulihan tersebut dengan merujuk kepada pasal 14 ayat (1) dan ayat (2) UUD NRI 1945. Melalui Pasal 14 Ayat (2) UUD NRI 1945 mengenai Amnesti dan Abolisi yang merupakan bagian dari hak prerogatif Presiden. hak prerogatif ini lebih berdimensi politik, meskipun presiden dalam pemberian amnesti dan abolisi perlu memperhatikan pertimbangan dewan perwakilan rakyat. Presiden juga memiliki hak berupa pemberian grasi dan amnesti dengan pertimbangan Mahkamah Agung sebagaimana yang dimaksud dalam ketentuan Pasal 14 Ayat (1) UUD NRI 1945. Pemberian grasi dimaksudkan untuk dapat mengurangi dan menghapuskan sebahagian dan keseluruhan tindak pidana yang

16 Adnan Jamal, “Redesain Model Kameralisme Parlemen dalam Sistem Ketatanegaraan Indonesia”, Halu Oleo Law Review (HOLREV), Volume 1, Issue 1, March 2017, http://ojs.uho.ac.id/index.php/holrev/article/view/2348, diakses pada tanggal 25 Februari 2018, hlm. 36. 
telah dijatuhkan oleh pengadilan termasuk pencabutan hak politik. Sedangkan rehabilitasi dimaksudkan sebagai bentuk pemulihan atas sebahagian dan keseluruhan hak karena telah ditemukan fakta hukum bahwa pihak-pihak yang dicabut haknya termasuk hak politiknya terbukti merupakan korban dari sebuah rezim dan tidak terbukti bersalah.

\section{KESIMPULAN}

Hak Politik merupakan hak yang dijamin oleh konstitusi dalam konteks negara hukum sebagai perwujudan atas penghormatan, pemajuan dan perlindungan hak asasi manusia dan demokrasi. Pemulihan hak Politik tanpa melalui mekanisme peradilan dapat dilakukan melalui mekanisme konstitusional yang dimiliki presiden sebagai kepala negara. Mekanisme konstitusional tersebut dijamin di dalam Pasal 14 Ayat (1) dan (2) UUD NRI 1945 tentang grasi dan rehabilitasi serta amnesti dan abolisi.

\section{Daftar Pustaka}

\section{Buku}

Budiardjo, Miriam, Dasar-Dasar Ilmu Politik, Jakarta: PT. Gramedia Pustaka Utama, 2008. Damayanti, Rizky Ridha, Pemulihan Hak Politik Dalam Sistem Hukum Indonesia, Tesis Surabaya: Universitas Airlangga, 2016.

Davidson, Scott, Hak Asasi Manusia: Sejarah, Teori, dan Praktek dalam Pergaulan Internasional, (terjemahan A. Hadyana Pudjaatmaka), Jakarta: Pustaka Utama Grafiti, 1994.

Djali et al,. Hak Asasi Manusia (Suatu Tinjauan Teoritis dan Aplikasi), Jakarta: CV, Restu Agung, 2013.

Marzuki, Peter Mahmud, Penelitian Hukum, Edisi Revisi, Jakarta: Prenada Media Group, 2016.

Wignjosoebroto, Soetandyo, Hak Asasi Manusia Konsep Dasar dan Perkembangan Pengertiannya dari Masa ke Masa, Jakarta: Lembaga Studi dan Advokasi Masyarakat Jakarta, 2005.

\section{Jurnal}

Jamal, Adnan, "Redesain Model Kameralisme Parlemen dalam Sistem Ketatanegaraan Indonesia", Halu Oleo Law Review (HOLREV), Volume 1, Issue 1, March 2017, 
http://ojs.uho.ac.id/index.php/holrev/article/view/2348, diakses pada tanggal 25 Februari 2018. 